\title{
Symptom Onset Date
}

National Cancer Institute

\section{Source}

National Cancer Institute. Symptom Onset Date. NCI Thesaurus. Code C119242.

The date and time on which the symptoms began or were first noted. 